\title{
6
}

\section{Socialist ideology and practical realism: the process of compromise in Vietnam's law on education}

\author{
Elizabeth St George
}

As part of the overall theme of this book, this chapter seeks to analyse how socialism has been influential in shaping law by examining the specific example of the Education Law of Vietnam, passed in 1998. Socialism, in its many incarnations, played a particularly important role in the development and elaboration of the Vietnamese Education Law, linked in part to the significance of the education sector as the principal vehicle for the transmission of socialist theory and ideology-even as its importance is being downplayed in other sectors. Socialism, in its various different forms, has had a variety of impacts on the structure and content of the Education Law. At times these have been in contradiction with the practical realities facing the Vietnamese education sector, leading to certain contradictions within the law itself.

While the Education Law covers all education levels, this chapter draws its practical examples principally from developments in higher education. This sector saw the most far-reaching changes while the law was being drafted, and was one where developments had a strong influence on shaping the way in which many important issues were addressed. The first section looks at the theoretical role of law in Vietnamese socialism, and shows that this role is far from resolved. Against this background, the chapter then goes on to look at the Education Law itself and the references to socialism and socialist theory (particularly Marxism-Leninism) it contains. Finally, it focuses on the issues surrounding three specific areas in the law - those of administration, financing and the role of education itself-and argues that, while socialist central planning and socialist theory have had a strong influence on the shape of the law, many areas show a break from these paradigms where they did not fit with wider social values or were contradictory to the perceived 
development path of the country. In short, this chapter argues that, while the Education Law purports to be supporting a socialist direction, that direction is focused very much on solving the practical realities facing Vietnamese society and theoretical paradigms are readily altered in the face of necessity.

The question of what is socialism is a particularly complex one, beginning as it does in political economic theory that has then been applied in practice to a number of different societies around the world. Consequently, the term has acquired many layers of meaning both from vigorous intellectual debate and from its concrete application in different countries for more than a century. Vietnam is avowedly a socialist republic, and the debate over the nature of socialism has become even more vigorous since the official acceptance of a market economic direction at the Sixth Party Congress in 1986 . While the country has maintained the name adopted since the reunification of the country - the Socialist Republic of Vietnam - the particular socialist path the country should take has not always been clear and the role of law within the country remains problematic.

This section seeks to understand the Education Law from the internal theoretical paradigm from within which it was written. This is a double challenge, first because a large number of people were involved in the formulation of the law, each with their different backgrounds and perspectives on the role of the law, and second because, while an outsider can bring important insights to a process that may not be evident to those involved, this perspective is necessarily based on second-hand accounts that may not fully reflect the complex considerations involved at the time. Despite these concerns, it is difficult to explain the socialist aspects of the Education Law fully, without reference to wider contemporary debates about the role and nature of socialist law in Vietnam.

The dominant paradigms from which those formulating the Education Law were operating were those of Marxist-Leninist theory, and the practical experience of Vietnamese education leaders over the past fifty years or so of Vietnam's history (also based in part on a long-standing Confucian heritage, emphasising respect for education).

In principle, all state and political activities in Vietnam must accord with the country's path to socialism, as decided by the Communist Party of Vietnam (CPV), on the basis of Marxism-Leninism and Ho Chi Minh thought. In other countries, 'Marxism' may refer not only to the writings of Marx and Engels, but also to a plethora of subsequent literature concerning the state, labour or a multitude of other topics, as well as the platforms of Marxist-inspired parties. In Vietnam, however, Marxism-Leninism and Ho Chi Minh thought refer specifically to the original writings of Karl Marx, Frederick Engels, V.I. Lenin and Ho Chi Minh, which are then reinterpreted in light of current circumstances and the 'objective realities' prevailing in the country at the time. Marxist-Leninist theory and Ho Chi Minh thought are the affirmed foundations on which the CPV bases its platform and leads the country. As stated at the opening to the Ninth Party Congress in 2001, the nation has a 'precious heritage-Ho Chi Minh thought which, combined with Marxism- 
Leninism, constitutes the ideological foundation and the lodestar for all actions of the Party and Vietnamese Revolution' (Communist Party of Vietnam 2001:4).

The place of both education and the law within this theoretical framework is an ambiguous one. In a theoretical system in which the driving forces of history are the relations of production between different classes, both the law and education are part of the superstructure, instruments that the ruling class is able to manipulate by virtue of its position of superiority. Under capitalism, therefore, where the ruling class is the bourgeoisie, law is an instrument that the bourgeoisie manipulates in its own favour. 'Law, morality, religion, are to [the proletarian] so many bourgeois prejudices, behind which lurk in ambush just as many bourgeois interests' (Marx and Engels 2000 [1887]:9). Marx was also suspicious of formal education. In his one specific reference to the subject in The Critique of the Gotha Program, he argues that the state and the church have had a very negative impact on the education of the people, and instead '...the state has need, on the contrary, of a very stern education by the people' (Marx 1947:42). Lenin was only slightly more positive about the role of education. While he recognised the importance of education campaigns to educate the masses about the nature of socialism, communism and revolution, '[1]ike the state, schools were held to be compulsory institutions that obstructed a truly socialist construction, and they should be allowed to wither away' (Lilge 1968:560). ${ }^{1}$

Marx and Engels distinguished five principal phases of historical progression that nations must pass through, based on their particular relations of production: slavery, feudalism, capitalism, socialism and finally communism. According to the $\mathrm{CPV}$, Vietnam is a country 'developing along the path to socialism'2 ${ }^{2}$, in more detail, the Ninth Congress in 2001 asserted that ' $[\mathrm{t}]$ he path forward of our country is transitional development to socialism, bypassing capitalism, in other words bypassing the establishment of the dominance of the production relations and the superstructure of capitalism'. ${ }^{3}$ In practice this should mean that capitalist characteristics - both governing through a system of laws, and developing a formal education system-are elements that should be bypassed. In the case of Vietnam, however, both are being strengthened.

In attempting to come to terms with this complicated and potentially contradictory situation, Dinh Van Mau and Pham Hong Thai (2002) in their foundational text for law school students, support the introduction of law in Vietnam by arguing that instead of automatically asserting that law is an instrument of the bourgeoisie, it is necessary to ask certain questions to understand the foundations on which the law is based: 'What is the economic basis of the law?' and 'Whose class interests are best served by the law?' (Dinh Van Mau and Pham Hong Thai 2002:210). They then go on to argue that laws in feudal societies supported the rule of kings and religion (Dinh Van Mau and Pham Hong Thai 2002), while the essence of capitalist law is to reinforce the interests of the capitalist class, among other things by protecting private property (Dinh Van Mau and Pham Hong Thai 2002) and excluding communist parties, which represent the interests of workers, from politics (Dinh Van Mau and Pham Hong Thai 2002). Under socialism the working class becomes the ruling 
class. Consequently, socialist law, by contrast with other forms of law, must necessarily reflect the will of the working class. The situation presented by the authors for Vietnam, however, does not fit this clear periodisation.

[S]ocialist law is the synthetisation of the rules of behaviour that give expression to the will of the working class and workers under the leadership of the Communist Party, and is decided by state offices and those with jurisdiction according to the order and the procedures laid down by the law, in order to readjust social relations in accordance with a market economy during the transition to socialism (Dinh Van Mau and Pham Hong Thai 2002:233). ${ }^{4}$

Although they do not mention Vietnam specifically, it is clear that the aim of the authors is to justify the use of law in Vietnam. They are left in a quandary, however, because they recognise that Vietnam has not yet reached the socialist stage of development and Vietnam is supporting a market economy. From a classical MarxistLeninist point of view their argument is highly suspect, if not contradictory in paradigm. In order to assert that laws in Vietnam are socialist, the authors argue that they reflect the will of the working class, and yet at the same time they recognise that the country has a market economy and is in transition to socialism-it has not yet reached socialism. According to the 'objective laws' of Marxism-Leninism, where the nature of the superstructure (law) depends on the relations of production and the nature of the economy, a market economy and pre-socialism (that is, effectively where capitalist relations are still present) are objectively highly unlikely to give rise to socialist laws that represent the interests of the working class.

While implicitly recognising this contradiction, the authors attempt to bypass it in order to justify the current Vietnamese situation. Although they recognise that the law is an instrument of the state, they argue that the state is guided by the Communist Party, which itself represents the interests of 'labourers, peasants and other types of labourers' (Dinh Van Mau and Pham Hong Thai 2002:238). Consequently they argue that the law is unlike that of capitalist countries which serves only those few who have taken over leadership of the state; rather, the 'socialist' law of Vietnam serves the will of all classes (Dinh Van Mau and Pham Hong Thai 2002:238). ${ }^{5}$

The authors not only justify the socialist nature of Vietnamese law, but also describe its particular content. They argue that socialist law is an instrument of the state that defines the operations and administration of the state, ensures the participation of all people in the state, and defines the limits of power between the different parts of the state. It also protects the different internationally recognised human rights and, importantly, it is a means to concretise the policies of the CPV and ensure their unified implementation (Dinh Van Mau and Pham Hong Thai 2002). Many of these concerns are present in Vietnam's Education Law.

The authors conclude that in the transitional phase to socialism there is a need for a system of laws so that the market economy can operate efficiently and guide the country to a higher stage of development (Dinh Van Mau and Pham Hong Thai 2002), when implicitly laws will no longer be needed. In theoretical terms, the leading role of the Communist Party in Vietnam is central to justifying the introduction of 
'bourgeois' laws. In short, socialist law in Vietnam is principally a set of instruments by which the state manages the country in accordance with the guidance of the CPV.

While this argument represents the view of only two authors, their work, as a basic university textbook, necessarily received high-level scrutiny and approval before it was introduced. That their conclusions are widespread is supported by a number of primary texts. The Ninth Party Congress documents, for instance, refer to the law instrumentally as a means to fight corruption and bring order to the civil service (Communist Party of Vietnam 2001), and the need to build socialist state law under the leadership of the Party (Communist Party of Vietnam 2001). ${ }^{6}$ The Textbook on Socialist Science, prepared by the Central Steering Committee for the Editing of National Textbooks for the Study of Marxism-Leninism and Ho Chi Minh thought, also emphasises the instrumental nature of laws. The fundamental aim of strengthening the legal system it argues-including the role of the National Assembly and the division of responsibilities in formulating laws-is to improve the administrative results of the state and the democracy of the people. ${ }^{7}$ It also emphasises that the democracy of the people is guaranteed by the leadership of the CPV guiding the state (Communist Party of Vietnam 2001:272).

Taken together, the arguments presented above lead to the conclusion that socialist law is a set of guiding rules and regulations that are formulated and implemented by the state (consisting principally of the different ministries and their local offices) under the guidance of the CPV in accordance with the process of political compromise that necessarily goes into documents based on wide consensus (such as the Documents of the Ninth Congress, national textbooks, and the Education Law). It is also an administrative tool that serves to ensure that the policies of the $\mathrm{CPV}$ are better applied than in the previous system of diffuse ordinances and regulations, combined with an appeal to people's morality (Dinh Van Mau and Pham Hong Thai 2002). In no instance is there any suggestion that the law exists as a means to ensure checks and balances within the system of governance or as an equal partner in the sense of executive, legislative and judicial branches of state. In practice, this situation creates a certain amount of ambiguity and tension because the law is simultaneously intended as a centralised administrative instrument of the Party-state, and, in the context of a burgeoning market economy, it regulates the areas in which the market economy-in this case the schooling system-is able to develop its own separate regulations and funding arrangements. It must walk the line between a background of socialist central planning and the practical realities where socialist central planning has already failed as a viable system of state management. These contradictions were carried through into the drafting process of the Education Law, and were evident in the final compromises that were reached.

Prior to the Education Law in 1998, education was managed by an ad hoc system of decrees and decisions produced by different authorities concerning their (overlapping) jurisdictions, and also by unwritten practices that were developed over time. ${ }^{8}$ The responsibilities of higher education institutions , for example, and 
their relationship to the state were decided by the individual regulations established on a case-by-case basis, in accordance with the general regulations governing the founding of HEIs in Vietnam established in 1963 (171/CP, 20/11/1963). These individual regulations were decided on application to the government by the MOET (or other ministry or provincial government office) and the State Planning Committee, with the submission of documents stipulating the institution's 'mission statement, planned teaching program, curriculum, method of teaching, enrolment and structure' (Minh Vu 1994:11).

Regulations concerning other issues-everything from the level of financing to the responsibilities of teachers-were dealt with by the particular department (vu) responsible for that area. The department would examine a problem and issue a decision, frequently with little consultation with any other department that might be concerned with the issue. The situation was further complicated at the provincial and district levels with extra levels of vertical and horizontal administrative hierarchies that administer secondary level schools and below. The decrees were signed by the minister or vice-minister, who was supposed to act as a filter to ensure that the decrees did not overlap or contradict each other. In fact, however, a number of contradictory decrees continued to be promulgated, allowing the institutions often to do much as they pleased. ${ }^{9}$ In 1995 Tran Chi Dao complained that

[t]here is a deficiency of current legal statutes that are relevant and appropriate to management of the changing situation in Vietnam's higher education institutions. This lack tends to make some institutions excessively dependent on the MOET while others exercise newly found initiative. Both patterns can affect the quality of education (Tran Chi Dao et al. 1995:89).

Case-by-case decision-making simultaneously gave institutions the leeway to interpret the decisions according to their interests, and created a climate of uncertainty in which institutions were unwilling to act. As there was no formal delineation of decision-making responsibilities between institutions and the central government, the latter could theoretically intervene in any area it deemed important. In the mid 1990s, for example, two national universities in Hanoi and Ho Chi Minh City were created on the basis of existing institutions. These universities were given special powers to develop and establish their own courses and open experimental classes in new subject areas. In practice, however, the MOET still required that all new courses be submitted for approval before beginning operation (St. George 2003). Effectively, the founding regulations governing the two new universities overlapped with the general regulations governing universities as a whole, leading to confusion and contradiction in their implementation, as well as delays in the introduction of new courses.

The first limited attempt to bring order to the very diffuse system of regulations in higher education appears to have taken place in 1985 with the introduction of the Provisional Regulation on the Responsibilities, Organisation Structure and Operation of Higher Education Institutions (17 July 1985). This regulation defined 
the general duties and responsibilities of institutions, including regular reports to the Ministry of Education and Training (MOET) and the overseeing ministry, the organisation structure and duties of different bodies within the institutions, and the rights and responsibilities of students, teachers and the rector (Minh Vu 1994:11).

Following further efforts to bring some order to the regulatory framework in education, the government continued to recognise the need for a comprehensive system of legislation, in which the roles and responsibilities of the different decisionmakers in the education sector were clearly spelt out. The situation was finally addressed in a comprehensive manner through the introduction of the Law on Education. This law underwent 23 drafts before the twenty-fourth was finally passed into law by the National Assembly, after extensive discussion, on 1 December 1998 (Tran Thi Tam Dan 1999).

The process of drafting the Education Law began in October 1995 when the government passed a resolution for work to begin, within the broad framework of building a nationwide system of law (Tran Thi Tam D an 1999). The law was drafted under the auspices of a special Party cell within the National Assembly, which formally began operation in January 1996 (Nhân Dân, 17 May 1997:1, 3). ${ }^{10}$ It was given responsibility for guiding the law through a process of consultation with a wide range of groups such as the MOET, government and Communist Party agencies concerned with education within the country, and other education specialists. The twenty-third draft, for example, was presented to 60 of 90 members of the National Assembly, those holding postgraduate degrees, in order for them to examine specifically the legal aspects of the draft (Nhân Dân Internet Edition, 21 September 1998). During the process of drafting and re-drafting, regular reports on the law were also presented to the National Assembly (Pham Min Hac 1998).

The extended process of drafting the law was undertaken to ensure a very wide input and opinion from among those with an interest in education. The process brought to the fore particular areas of contention among the interested parties, such as the level of detail the law should contain, administrative procedures, and sources of finance. The final law reflected a complex process of negotiation and compromise between the interested parties, in which the commitment to a socialist order remained an important concern.

In the final event, the Education Law of Vietnam passed by the National Assembly comprises 110 articles that cover in general the aims, levels and types of education, as well as the roles and responsibilities of teachers, students and the state with regards to formal education from crèche through to $\mathrm{PhD} \mathrm{level.}$

Within the Education Law, four principal articles contain direct references to socialism, Marxism-Leninism or Ho Chi Minh thought, highlighted above as the foundational texts and guiding lights of Vietnamese socialism. ${ }^{11}$ These references to socialism cover two principal areas: the aims of education in Vietnam and the content of the educational curriculum at higher levels of education. The aims and principles of education in Vietnam are contained in Articles 2 and 3. According to Article 2, 
[t] he aim of education is to comprehensively develop Vietnamese people through training so that they have ethics, intellectual ability, health, an aesthetic sense and a profession, faithful to an independent nation and socialism. ${ }^{12}$

\section{Article 3 further reinforces the socialist nature of Vietnamese education}

Vietnamese education is socialist education that is popular, national, scientific, ${ }^{13}$ modern, and laid on a foundation of Marxism-Leninism and Ho Chi Minh thought. ${ }^{14}$

In order to support these general aims, a further specific aim of primary and secondary education is to develop the socialist character of the Vietnamese people (Article 23), so that they can undertake further study. ${ }^{15}$

Article 35 concerning the aims of higher education does not directly mention socialism or socialist thought, instead this is taken up in the following article concerning the content of higher education (including postgraduate education) programs.

The content of higher education must be modern and developed, ensuring an appropriate structure divided between basic scientific knowledge and specialist knowledge, as well as containing the scientific subjects of Marxism-Leninism, and Ho Chi Minh thought (Article 36 , Section 1a). ${ }^{16}$

A similar statement is repeated for the content of postgraduate education, although with greater emphasis on developing research capability (Article 36, Section 2a).

The Education Law asserts its socialist character by committing the national education system to building socialism in the country, as well as to creating people who are socialist in character. It confirms that Vietnamese education is socialist in nature, or more specifically that it is based on the teachings of Marxism-Leninism and Ho Chi Minh thought, particularly for university and postgraduate education.

Not only is socialist theory an important basis for the national education system, higher levels of study are also expected to contribute actively to the perpetuation and actualisation of socialism. This is particularly evident in the Law on Science and Technology (Luat Khoa hoc va Cong nghe). It is worth pointing out here that the English term 'science' as generally used does not do justice to the multiplicity of meanings of the Vietnamese term khoa hoc. Not only does khoa hoc refer to the study of physical sciences, but also to higher levels of theoretical study across all fields of enquiry. By extension it also refers to logical methods of enquiry and, further, to research and the application of theory in any discipline. The Law on Science and Technology, then, refers to the duty of science and technology activities as being (among other things) to

creatively develop and apply the reasoning of Marxism-Leninism and Ho Chi Minh thought; to build socialist reasoning and the path to socialism in Vietnam (Article 4, Section 1). ${ }^{17}$

In other words, while educational activities are required to transmit the tenets of socialism, people conducting scientific study (or research) are not only expected to apply them in their own research, but they are also expected to support and build the theoretical foundations underpinning socialism itself. The important political role of research is even more clearly inferred further on, where science and technology 
activities are strictly forbidden from being used for any activities that 'misrepresent or go against the line or the policy of the Communist Party of Vietnam, the laws of the Socialist Republic of Vietnam or undermine national unity' (Article 8, Section $2){ }_{1}^{18}$ where the 'line or the policy' of the CPV is fundamentally to bring Vietnam along the path to socialism. ${ }^{19}$ Clearly, those involved in elaborating both the Education Law and the Law on Science and Technology felt that there were important links that needed to be maintained between education, research and the socialist system in Vietnam.

Explicit references to socialism are not necessarily the norm in Vietnamese laws. The Law on Commerce, for example, only makes explicit reference to socialism in the name of the country, the Socialist Republic of Vietnam. The aims of the law given in the introduction refer to the role of commerce as ensuring the growth of production, improving the lives of the people, and strengthening the nation (among others), rather than to supporting the foundations of socialism. ${ }^{20}$ The introduction to the Labour Code (Bo Luat Lao Dong) likewise refers to one of the aims of the law as being to implement the CPV's policies, but makes no reference to supporting MarxismLeninism or upholding socialism. ${ }^{21}$

The significance of references to socialism is not only that they serve to underpin the socialist character of the law, but that they make explicit its political orientation, a characteristic also evident in the largest remaining socialist country, the People's Republic of China. The Law on Compulsory Education of the People's Republic of China, for example, also specifies that the law is 'for the purpose of promoting elementary education and the building of a socialist society that is advanced culturally and ideologically as well as materially' (Article 1), while further on it expresses support for the state policy on education, which, among other things, aims to cultivate 'well-educated and self-disciplined builders of socialism with high ideals and moral integrity' (Article 3) (People's Republic of China 1986). Even the 2002 Law on 'People-founded' Schools specifies that these schools (which are based on non-state funding) are part of the socialist education system (Article 3) and that they serve to construct socialism in the country (Article 4) (People's Republic of China 2002).

By comparison, in Australian legislation on education, for example, references to a particular political orientation are noticeably absent, ${ }^{22}$ although many of the other educational aims put forward are virtually the same as those found in the Chinese and Vietnamese laws, including national development, ${ }^{23}$ and the intellectual, physical and moral development of students in general education. ${ }^{24}$

David Paris' (1995) analysis of educational reform in the United States argues that the liberal democratic theory on which the US school system is based in fact creates significant difficulties for educational reform because it permits a plurality of perspectives in the approach to, and implementation of, education policies, and this results in a plurality of conflicting ideals guiding policy. Concretely, this means that guiding documents on education tend to avoid presenting higher guiding directions, in favour of setting practical milestones. Consequently, when George 
Bush (Snr) put forward the country's new educational strategy in 1989, it was couched in the very practical terms of particular goals to be achieved. Paris argues that, while these goals represented consensus, they avoided the ideological importance of education and became the foundations of conflict in subsequent efforts to achieve these goals (Paris 1995). While Paris is referring to educational strategy rather than education law, it is worth noting that even the 2001-10 Vietnamese education strategy, which contains very detailed education goals (in terms of enrolment, funding, teaching methods and so forth), nonetheless insists on the role of education in following the country's ideological direction by modernising the country and building socialism (Cong Hoa Xa hoi Chu nghia Viet Nam 2001:18). Vietnam's law takes the opposite extreme to that highlighted by Paris for the United States. In Vietnam, the ideological direction is clearly stated, both in the law and in the translation of that law into policy documents, such as the Education Strategy, which concentrates on setting particular targets to achieve educational goals, under the guiding framework provided by the law.

In short, the Vietnamese Law on Education clearly identifies its own socialist nature, which, by its content and concerns, also places it in line with similarly selfavowedly socialist education laws, such as those of China. From this socialist perspective, education is an intrinsically ideological and political activity, and should be asserted clearly at the highest levels of legislation. During the process of drafting the Education Law, therefore, the more contentious issues debated revolved less around whether to include references to ideology, but rather the relative importance that should be given to ideology and to the role of the law in defining levels of authority and responsibility - that is, administrative and organisational issues. They also revolved around the appropriate place of non-state funding, but despite the suspicion with which Marx and Lenin regarded education, there was little debate about the high level of importance that should be attached to this sector.

Administrative issues are best highlighted in a comparison of the sixteenth draft of the law, from December 1996, and the law that was finally passed in December 1998. The introductions to the $1996 \mathrm{draft}$ and the 1998 law set the contrast between the two. In the $1996 \mathrm{draft}$, the stated purpose of the law is to define the relationship between different organisations responsible for education in Vietnam, and their role in achieving a modern education system. It also serves to 'legitimate viewpoints and directions of education renovation adopted by the Party and State'. It concentrates on the organisation of education, against the background of current policies, although it allows for the possibility that these 'viewpoints and directions' may change. By mid 1997, however, the draft law had begun to emphasise the role of the law as being to structure the policies and work of the Communist Party and the state in education (Giao duc va Thoi dai [Education and the Age], 1 May 1997:1, 3 ), and this was carried through into the law that was finally passed.

The introduction to the 1998 law is principally a Communist Party of Vietnam policy statement, in which the importance of organisation and administration receive only a passing mention. It stresses that the law is aimed at improving education in 
the country so that it benefits development, and it is virtually a direct copy of statements regarding education made at the Eighth Communist Party National Congress, held in 1996. The education law aims to

develop education, raise the effectiveness of the state in administering education, raise the people's intellectual standard, train human resources and groom talent to achieve the industrialisation and modernisation of the country, to meet the needs of building and protecting the nation, with the aim of creating a rich, strong, equitable and civilised society.

'Industrialisation and modernisation' in particular are the hallmark slogans of the Eighth Party Congress.

Interestingly, an article that appeared in the Communist Party daily Nhân Dân when the National Assembly was considering the twenty-third draft of the law complained that the law had been given to sectoral specialists (that is, educators from the MOET) rather than legal experts and therefore lacked legal standards and was not in line with standardisation across the country (Nhân Dân Internet Edition, 10 November 1998). This suggests that the standardisation should comply with broad national policies rather than sectoral objectives, which were the focus of previous drafts.

Compared to the 1996 draft, the 1998 law envisaged a reduced role for the state, and increased responsibilities for educational institutions. Article 105 (1996) specifies that the state organises special schools for disabled students from crèche through to the final year of compulsory education, while Article 58 of the 1998 law states that ' $[\mathrm{t}] \mathrm{he}$ state founds, and encourages other organisations and individuals to found schools and classes for disabled people [emphasis added]'. Organisations other than the state are given an opening to take a more active role in educational activities.

In another example, the 1996 draft specifies that the state encourages links between educational institutions, social organisations, businesses and the society at large (Article 95), although schools play the leading role in links between society and education (Article 108). By contrast the final 1998 law specifies that individual educational institutions are to establish their own regulations of operation, covering, among other things, the relationship between the school, families and society (Article 48 , para 2). In other words, the final law is far more encouraging of educational institutions being pro-active in seeking their own relationships with the wider community, something that would have been unthinkable under socialist central planning.

Another area that shows a reduced role for the highest levels of the state is postgraduate education. In 1976 the Party Central Committee established postgraduate education in the country for the first time (QĐ224/TTg, 24/5/1976). At that time, matters concerning postgraduate education were to be looked after by a specialist government committee, with the assistance of the Ministry of Higher Education (as it was at the time). Any institutions providing postgraduate training, which were largely research institutes rather than teaching universities, had to report their activities to this committee, and doctoral candidates had to defend their 
thesis in front of an examination committee appointed by the Prime Minister. Topics of research were also closely coordinated with the relevant ministry responsible for that area of research and the government committee on education. Candidates were expected to be strong supporters of the Communist Party and its policies, and to 'put into practice the path and policies of the Party and government, maintain a truthful attitude and help socialism' (QĐ 224/TTg, 24/5/1976).

Since the early 1990s, universities have been taking a far more active role in postgraduate education, especially at the Master level, but this has continued to receive a very high level of interest from the central government. For doctoral-level study, no committee is guaranteed formal oversight of their provision any longer (although in practice it continues to exist), nor are candidates given preferential treatment based on their involvement with the Party (although many doctoral candidates continue to be members of the Communist Party). One of the areas of hottest contention during the final National Assembly debates on the law was what level of authority (minister or higher education institution rector) should be responsible for awarding postgraduate degrees (Nhân Dân Internet Edition, 10 November 1998). The solution adopted was to maintain the status quo with regards to PhD degrees-the minister continues to award them (Article 39), but to delegate responsibility for Masters degrees to the rector of the university. In the $1996 \mathrm{draft}$, the rector first had to seek approval from the Minister of Education (Article 157), but this stipulation was dropped from the final law (see Article 39, para 3), very likely because of the increasingly large number of students who are graduating with Master degrees in Vietnam, which would have heavily increased the workload of the minister or their deputy. Despite the introduction of the law, other regulations govern the requirements and procedures for the award of postgraduate degrees in more detail (QĐ 647/GD-ĐT, 14/12/1996; Minh Vu 1994).

That socialist nature is also in line with the dominant understanding of the role of socialist law as an instrument by which to implement the guiding policies of the $\mathrm{CPV}$. In a close echo of the Eighth Party Congress documents and the introduction to the law, according to the magazine Education and the Age [Giao duc va thoi dai], the reason for establishing the law was to structure the policies and work of the Communist Party and the state in education, and to reassert the leadership of the Party, the administration of the state, and the participation of the people. It also seeks to assert the responsibilities of state organisations at each level within education, under the unified management of the state (Giao du va Thoi dai [Education and the Age] 1997:1,3). While the issue of division of responsibility is certainly addressed in the law, and responsibilities of the Ministry of Education and Training at the central level are mentioned, this division remains largely at the level of principles, rather than specifying the concrete measures to ensure that clarification of division of responsibility becomes a reality. For example, the individual school authorities are under the administration 'of all education administration offices ${ }^{25}$ in accordance with the powers delegated by the central government (Article 44). 
The scope of authority of different levels of government (provincial, district, and so forth) are only specified in very specific areas, such as the award of graduation certificates and degrees (Articles 27,33,39). Other areas are left under the general supervision and administration of the central government, reflecting the strong influence of a recent tradition of socialist central planning.

In the area of curriculum, the division of responsibility remains highly centralised. The central government, through the MOET, maintains the primary responsibility for courses at primary and secondary levels of education, and also has significant responsibility for higher levels. At general education levels, this responsibility is exercised in particular through the compilation and publication of textbooks, which are approved by a national council before being introduced (Article 25). Universities and colleges are able to compile and produce their own textbooks in specialist areas of teaching, after approval by a curriculum committee established by the rector of the institution (Article 37), but only in branches of study (nganh) for which the institution has already received permission to teach (Article 55). Given that any new subject may be considered a new branch of learning, the distinction between the two is not always clear, and can be manipulated by the government as well as higher education insitutions to suit their own interests. In subject areas that are prescribed by the MOET for all college and university degrees (such as MarxistLeninist theory, Marxist-Leninist political economy, national defence, sport), the MOET is also responsible for producing the relevant textbooks and courses of study (Article 37), and their use is further reinforced through subordinate legislation that specifies, for example, how many hours and which chapters of the textbooks should be studied by different groups of students. ${ }^{26} \mathrm{In}$ fact, the only areas of education for which the state does not produce compulsory textbooks are postgraduate education (where supervision is exercised through the oversight of graduation theses), vocational education, and 'non-regular' (khong chinh quy) forms of education, such as literary courses, professional skills upgrading courses and courses specially designed to meet student demands. Part-time courses, distance education, guided study or any course leading to an award within the national education framework must also be approved by the MOET (Article 41).

Despite many areas of the law in which the division of responsibility remain unclear, it is clear that at an official level the development of curriculum remains a highly sensitive and highly centralised undertaking. In other areas there is a clear trend towards greater decentralisation of educational responsibility, in favour of institutions, but the biggest area of contention, and the area that remains most vague in the law is that of the decentralisation of education funding.

If the opening-up of the country and the introduction of doi moi were in part a response to the deepening financial crisis of the late 1970s and 1980s, then nowhere was this more evident than in the education sector, where inflation drastically eroded teachers' salaries, and vocational colleges and secondary specialist colleges (truong chuyên nghiep) were forced to close (Le Viet Khuyen c1998). Practical experiments 
with fee-paying students began as early as 1986 in Ho Chi Minh City, and the first fully non-government funded classes in higher education opened in Hanoi in 1988, as a direct response to the crisis situation in the country (St George 2003). From a legal perspective, these activities were in direct contravention of the 1980 constitution, which specified that the provision of education is the prerogative of the state (Article 41), and that education must be provided free of charge (Article 60). In 1992, these provisions were replaced in the revised constitution to allow for a system of 'fees and scholarships' at higher levels of education (Article 59). In other words the constitution was amended to reflect directly the changed practical realities of the Vietnamese education system, at the expense of strict ideological orthodoxy.

The Education Law also acknowledges the need for outside funding of higher educational institutions, by recognising the existence of school authorities in higher education institutions that are public, semi-public, people-founded and private (Article 44), ${ }^{27}$ although such institutions are not mentioned for other levels of study. The law also encourages organisations and individuals to contribute financially to education, for which they will receive tax exemptions (Article 91). Despite this acknowledgement of the importance of private contributions to education, there are no further details about the role of such funding in a state dominated education sector, nor any references to clarify the differences between these institutions and their relationship to the state. The final law leaves the founding of all educational institutions up to individual government decisions, such as those that have been used to govern the country in the past (Articles 46 and 47). This is in direct contrast to the 1996 draft (Article 90), which clearly specifies the means for the establishment of private institutions and outlines the responsibilities of such schools.

There are several explanations for the omission in the final law. At the time the law was being finalised there was significant criticism of the quality of private institutions, which were enrolling students at a tremendous rate without always paying attention to the number of teachers, classrooms, or the need for sufficient equipment to ensure the standard of their graduates (St George 2003). Questions were also raised about whether non-government schools and non-regular modes of study should really be considered part of the national unified system of education (Cao Cuong 1998). Finally, those drafting the law discussed, to an extent, the role of the law itself and how specific it should be. ${ }^{28}$ The result is that private education's role and rules of operation within the national education system remain vague and subject to subordinate decrees and regulations. On the one hand this shows the reluctance of central government figures to consider privately funded education as a permanent part of the Vietnamese education system (as opposed to a temporary measure to resolve current financial difficulties), on the other hand it reflects the serious concern about the quality of graduates from such institutions.

In general, the issue of income generation for schools apparently remains difficult to reconcile ideologically. Article 17 'forbids all actions commercialising educational activities' ${ }^{\prime 2}$ but at the same time Article 54 gives permission to higher education institutions to use economic activities (hoat dong kinh te) in order to earn money for 
educational activities. The prohibition against the commercialisation of educational activities implies both that education is in itself a non-productive activity (hence it can be 'non-commercial') and at the same time that education will somehow be contaminated if it is put on a commercial footing. Article 54, by contrast, appears to accept the reality that the state is unable to supply the financial needs of higher education institutions and to recognise the benefits that outside funding can bring. Dang Ba Lam, Director-General of the National Institute for Education Development, who was involved in the drafting of the law, agreed that the law was contradictory to some extent on this point, but argued that the main aim of the injunction against the commercialisation of education was a moral one. ${ }^{30}$ This, he suggested, was an appeal to people's moral sense not to misuse the highly respected tool of education for personal gain. The Education Law, therefore, while attempting to bring order to the diffuse system of rules and regulations, and better define the relationship between the state and educational institutions, has nonetheless not abandoned the system of regulating society by 'appealing to people's morals', underscoring the background on which the current law was built. In effect it shows a process of political compromise, in which ideological orientations have been bent, but not entirely forgotten, in the face of real economic necessity.

The issue of funding in education remains ideologically sensitive, as highlighted by the contradictions in the law itself mentioned above, and emphasised even more forcibly by the many funding issues that are left out of the law. At the same time, if state organisation in education and education financing are two areas that show the strong influences of 'socialism', then the issue of education itself is one that has broken radically from its ambiguous status in Marxist-Leninist writing.

As outlined earlier, according to classical Marxist-Leninist theory, education is a part of the superstructure, and its nature depends on the underlying relations of production in the economy. Consequently, both Marx and Lenin only supported education insofar as it raised the socialist conscience of workers. Ho Chi Minh $(1972: 68-73,89)$ emphasised that education needed to have a practical orientation, to support the building of socialism in the country.

Vietnamese leaders in the 1990s have thoroughly laid to rest this hesitant attitude. The constitution adopted in 1992 specifies that '[e]ducation and training is the priority national policy' (Article 35), ${ }^{31}$ and this assertion is repeated in the introduction to the Education Law, and again in the Ninth Party Congress documents (Communist Party of Vietnam 2001). In more detail, education is the means to 'bring into play human resources - the basic factor to develop the society, and create rapid and stable economic growth' ${ }^{32}$ According to the consensus represented by the National Party Congress, education is a direct input for economic growth. In other words, it no longer sits in a dependent relationship outside the economy, as part of the superstructure. The Ninth Party Congress further stressed the importance of education as the basis for ensuring that the country achieves the necessary preconditions for advanced technology and science, which are, again, necessary for the development of the country (Communist Party of Vietnam 2001). 
The greater importance placed on education is also evident in the practical measures taken by the government to bolster education. Teachers now receive priority salary payments compared to other public servants, and education is the only sector to have its budget proportion fixed and approved by the National Assembly at the high levels of 15 per cent for 2000, 18 per cent for 2005 and 20 per cent for 2010,33 planned levels that are apparently being achieved (Dang Ba Lam 2003). Student enrolment in higher education institutions, some of the less practically oriented areas of education, has also risen very rapidly, from 593,884 students in 1996/7, to 974,119 students in 2001/2. While the majority of students continue to study in public institutions, the number in non-state institutions has increased significantly as a proportion of the total, from 25,012 in 1996/ 7 to 100,900 in 2001/2 (from 4.2 per cent to 10.4 per cent of total students), although this proportion has been slowly falling since 1999/2000 (Dang Ba Lam 2003:518).

Prior to 1986, and even in 1991, National Party Congress documents tended to emphasise the role of education in teaching socialist principles and vocational skills, as in classical socialist writings, but during the 1990s, and particularly by the time the Education Law was finalised, the leadership of the country had firmly internalised international thinking about the importance of education as an input for the development of a country (St George 2003), and concretised support for education in practical policies and measures to support its now vital role in the development of the country. This shows a willingness of the part of the leadership not only to be swayed by practical realities, such as allowing private funding for education in the wake of the country's financial crisis, but also to be swayed by alternative theoretical paradigms that had shown their practical importance in other countries, in this case those of human resource development and of the knowledge-based economies (St George 2003). In the case of the latter, this support inadvertently tapped the traditionally high regard accorded to education in a Confucian society, where national examinations for advancement have been held for almost a thousand years. Within this framework, the determination to ensure that socialism and Marxist-Leninist studies are still included in education programs, particular at higher levels of study, can be seen as a compromise-an attempt to maintain the trappings of a socialist education system and guard against accusations that the Vietnamese education system might be becoming bourgeois, or capitalist.

Vietnam's education law purports to be socialist and yet the nature of that socialism is ambiguous. On the one hand it claims to rest on a foundation of Marxism-Leninism and Ho Chi Minh thought, and this background is still evident in the references to Marxism-Leninism and in the highly centralised administrative system provided for in the law. On the other hand, the makers of the law were confronted by a very real set of problems facing education in the 1990s, in terms of administration, finance and the role of education itself. In administration, institutions were hampered in their ability to adapt to a changing world because of a highly centralised decision-making structure. In terms of finance, there was great reluctance to accept non-state funding as a permanent feature of the education 
system, not only because of ideological and moral concerns, but also because of very real practical concerns about educational quality, and this is evident in the great vagueness of the law on matters of education funding. Finally, in terms of education itself, while Marxism-Leninism treats education with great scepticism, Vietnamese educators have also been keen to take on board international theories of education radically different from those of the nineteenth and early twentieth centuries. They have strongly welcomed international thinking supporting a strengthened role for education in socioeconomic development, to the point where it has been enshrined in the constitution as the 'priority national policy' of the country (Article 35).

In the final analysis, the socialist background of those drafting the Vietnamese Education Law clearly shaped the issues that were (and were not) addressed in the law, as well as the context in which the debates to finalise the law took place. Marxist-Leninist theory and socialist central planning shaped the theoretical perspective from which the Education Law was written, but this theoretical background was tempered by the practicalities of Vietnamese education. While this chapter has focused on the role of socialism in the Education Law, it is worth remembering that the realities of Vietnamese education, as for any other sector, are usually determined less with reference to the law, but rather on a basis that is established through daily social interaction, personal relationships and changing perceptions of the current problematic. Over time, these changing perceptions will no doubt occasion further adjustments to the Education Law in accordance with the changes to the 'objective realities' of socialism in Vietnam.

\section{NOTES}

1 Further information on the role of education in Marxism-Leninism and in other socialist writings can be found in St George (2003).

2 'Phat trien theo con duong xa hoi chu nghia' (Communist Party of Vietnam 2001:12).

3 The original text in Vietnamese was 'Con duong di len cua nuoc ta la su phat trien qua do len chu nghia xa hoi bo qua che do tu ban chu nghia, tuc la bo qua viec xac lap vi tri thong tri cua quan he san xuat ve kien truc thuong tang tu ban chua nghia...' (Communist Party of Vietnam 2001:21).

4 The original text in Vietnamese: 'phap luat xa hoi chu nghia la tong hop nhung quy tac xu su the hien y chi cua giai cap cong nhan va nhan dan lao dong duoi su lanh dao cua Dang cong san, do cac co quan nha nuoc, nguoi tham quyen ban hanh theo trinh $t u$, thu tuc luat dinh, nham dieu chinh cac quan he xa hoi, phu hop voi nen kinh te thi truong trong thoi ky qua do len chu nghia xa hoi chu nghia' (Dinh Van Mau and Pham Hong Thai 2002:233).

5 Clearly this raises another contradiction as to how the Communist Party can represent at the same time the interests of the working class and all other classes equally, and still remain a Communist Party.

6 'Xay dung Nha nuoc phap quyen xa hoi chu nghia duoi su lanh dao cua Dang [Building a state based on socialist law under the leadership of the Party]'.

7 The Central Steering Committee supervises the editing of national textbooks for the study of Marxism-Leninism (The Vietnamese text is 'Hoi dong trung uong chi dao bien soan giao trinh quoc gia cac bo mon khoa hoc Mac-Lenin' (Communist Party of Vietnam 2001:273)).

8 Sections concerning the drafting of the law, including comparisons with the $1996 \mathrm{draft}$ of the law are adapted from chapter 5 of St.George (2003).

9 Personal communication with MOET official, Hanoi, July 1998.

10 Other sources say that drafting of the law began well before these dates, in 1994, but this seems unlikely ('Vietnam Passes First Education Law', AFP News Bulletin, 5 December 1998). 
11 A quick survey of theoretical articles in journals such as Tap chi Cong san [the Communist Party Journal] or Phap ly va Nha nuос [Law and the State] quickly reveal that the majority of references to theoretical works are directly to the original works of Marx and Engels, to the writings of Ho Chi Minh, or less often to the writings of Lenin, rather than the later body of extensive works that now comprise 'socialist theory'.

12 The original text in Vietnamese is 'Muc tieu giao duc la dao tao con nguoi Viet Nam phat trien toan dien, co dao duc, tri thuc, suc khoe, tham my va nghe nghiep, trung thanh voi ly tuong doc lap dan toc va chu nghia xa hoi...'.

13 'Scientific' (khoa hoc) refers less to the applied sciences as usually meant in English, but rather to all higher level research. See below.

14 The original text in Vietnamese is 'Nen giao duc Viet Nam la nen giao duc xa hoi chu nghia co tinh nhan dan, dan toc, khoa hoc, hien dai, lay chu Mac-Lenin va tu tuong Ho Chi Minh lam nen tang'.

15 The original text in Vietnamese is 'Muc tieu cua giao duc pho thong la...nham hinh thanh nhan cach con nguoi Viet Nam xa hoi chu nghia, xay dung tu cach va trach nhiem cong dan...'.

16 The original text in Vietnamese is 'Noi dung giao duc dai hoc phai co tinh hien dai va phat trien, bao dam co cau hop ly giua kien thuc khoa hoc co ban voi kien thuc chuyen nganh va cac bo mon khoa hoc Mac-Lenin, tu tuong Ho Chi Minh...'.

${ }_{17}$ The original text in Vietnamese is 'Van dung sang tao va phat trien ly luan cua chu nghia Mac-Lenin va tu tuong Ho Chi Minh; xay dung ly luan ve vhu nghia xa hoi va con duong di len chu nghia xa hoi сua Viet Nam...'.

18 The original text in Vietnamese is 'Loi dung hoat dong khoa hoc va cong nghe de xuyen tac, chong lai duong loi, chinh sach cua Dang Cong san Viet Nam, phap luat cua Nha nuoc Cong hoa xa hoi chu nghia Viet Nam; pha hoai khoi dai doan ket dan toc.'

19 The original text in Vietnamese is 'Dang khang dinh chu nghia Mac-Lenin va tu tuong Ho Chi Minh la nen tang tu tuong va kim chi cho hoat dong cua minh' in Central Steering Committee for the Editing of National Textbooks for the Study of Maxism-Leninism (2002).

20 Luat Thuong mai 1997 [Law on Commerce 1997]

${ }_{21}$ Luat 35/2002/QH10 cua Quoc Hoi sua doi bo sung mot so dieu cua Bo Luat Lao dong [Labour Code of the Socialist Republic of Vietnam-Amended and Supplemented in 2002].

22 See, for example, Commonwealth of Australia, Higher Education Funding Act 1988, Article $2 a$.

23 See the Compulsory Education Law of the People's Republic of China 1986, Article 3; and the Law on Education (1998) of the Socialist Republic of Vietnam, Article 2.

24 See the New South Wales Education Act (1990), Article 6.1A; and Socialist Republic of Vietnam (1998), Law on Education (1998) of the Socialist Republic of Vietnam, Article 23.

25 The original in Vietnamese is 'cac co quan quan ly giao duc'.

26 See, for example, Quyet dinh so 19/2003/QD-BGDDT ngay 8/5/2003 cua Bo truong Bo Giao duc va Dao tao ve viec ban hanh De cuong mon hoc: Triet hoc Mac-Lenin; Kinh te chinh tri Mac-Lenin (khoi nganh kinh te - quan tri kinh doanh) va Kinh te chinh tri Mac - Lenin (khoi nganh khong chuyen kinh te - quan tri kinh doanh) trinh do cao dang [Decision No.19/2003/ QD-BGDDT, dated 8/5/2003, of the Ministry of Education and Training on the promulgation of the subject: Marxist-Leninist theory, Marxist-Leninist political economy (for economics and business management branches), and Marxist-Leninist political economy (for non-economics and business management specialisation branches) at the college level]. Similar decisions for other branches and subjects appear in the same edition of the national gazette, Cong Bao No. 45, 1 June 2003.

27 The difference between these four types of institutions has become increasingly unclear over time. One of the proposed amendments to the Education Law to be put to the National Assembly in 2004 includes reducing the number of types of institutions to two-public (to include semi-public) and private (including 'people-founded'). Personal communication with Dang Ba Lam, Director-General, National Institute for Education Development, Hanoi, 22 May 2003.

28 Personal communication with Dang Ba Lam, Director-General, National Institute for Education Development, Hanoi, 22 May 2003.

29 The original text in Vietnamese is 'Cam moi hanh vi thoung mai hoa hoat dong giao duc'.

30 Personal communication with Dang Ba Lam, Director-General, National Institute for Education Development, Hanoi, 22 May 2003. 
31 The original text in Vietnamese is 'Giao duc va dao tao la quoc sach hang dau'.

32 The original text in Vietnamese is 'phat huy nguon luc con nguoi - yeu to co ban de phat trien xa hoi, tang truong kinh te nhanh va ben vung' (Communist Party of Viet Nam 2001:108-9).

33 Communist Party of Viet Nam (2001), and Personal communication with Perran Penrose, UNDP consultant, Hanoi, 3 June 2003.

\section{REFERENCES}

Commonwealth of Australia, 1988. Higher Education Funding Act 1988, Commonwealth of Australian, Canberra.

Cao Cuong, 1998. 'National Assembly discusses Draft Education Law', Saigon Times Daily News Brief, 17 November.

Communist Party of Vietnam, 2001. Van kien dai hoi dai bieu toan quoc lan thu IX [Documents from the Ninth National Representative Congress], The Gioi Publishers, Hanoi.

Cong Hoa Xa hoi Chu nghia Viet Nam [Socialist Republic of Vietnam], 2001. Chien luoc phat trien giao duc 2001-2010 [Education Development Strategy 2001-10], Nha Xuat ban Giao duc, Ha Noi.

Quoc hoi Cong hoa Xa hoi Chu Nghia Viet Nam [National Assembly of the Socialist Republic of Vietnam], 1997. Luat Thuong mai [Law on Commerce], Luat so: 5/ 1997/QH9, Communist Party of Vietnam, Hanoi.

Central Steering Committee for the Editing of National Textbooks for the Study of Maxism-Leninism, 2002. Giao trinh chu nghia xa hoi khoa hoc [Textbook on Socialist Science], Nha Xuat ban Chinh tri Quoc gia, Ha Noi.

Dang Ba Lam, 2003. Giao duc Viet Nam nhung thap nien day the ki XXI - Chien luoc phat trien [Vietnamese Education in the First Decades of the Twentieth Century], Nha Xuat ban Giao duc, Hanoi.

Dinh Van Mau and Pham Hong Thai, 2002. Ly luan chung ve nha nuoc va phap luat [General Theory on the State and Law], Nha Xuat ban Tong hop Dong Nai, Dong Nai.

Giao duc va Thoi dai, 1997. 'Ve du an luat giao duc [Concerning the Education Law project]', Giao duc va Thoi dai, 1 May: 1, 3

Ho Chi Minh, 1972. Ban ve cong tac giao duc [Discussion on Educational Work], Nha Xuat ban Su that, Ha Noi.

Le Viet Khuyen, c1998. Dai hoc Viet Nam say 10 nam doi moi [Vietnamese Universities after Ten Years of Renovation], Mimeo, Hanoi.

Lilge, F., 1968, 1977. 'Lenin and the politics of education', in J. Karabel and A.H. Halsey (eds), Power and Ideology in Education, Oxford University Press, New York:556-72.

Marx, K., 1947. Critique of the Gotha Program, Foreign Languages Publishing House, Moscow.

Marx, K. and Engels, F., 1848 [2000]. Manifesto of the Communist Party. Marx/Engels Internet Archive, http:/ / marxists.org. 
Minh Vu, 1994. Legislative Framework for Higher Education in Vietnam, Princeton University, Princeton, New Jersey (unpublished).

New South Wales Government, 1990. New South Wales Education Act 1990, New South Wales Government, Sydney.

Paris, D.C., 1995. Ideology and Educational Reform: themes and theories in public education, Westview Press, Boulder.

People's Republic of China, 1986. Compulsory Education Law of the People's Republic of China, People's Republic of China, Beijing.

— 2002. Law to Step up People Founded Schools in the Socialist Republic of China, People's Republic of China, Beijing.

Pham Minh Hac, 1998. Vietnam's Education: the current position and future prospects, The Gioi Publishers, Hanoi.

Socialist Republic of Vietnam, 1998. Law on Education, Socialist Republic of Vietnam, Hanoi.

St George, E., 2003. Higher Education in Vietnam 1986-1998: education in transition for development?, PhD dissertation, Department of Political and Social Change, Research School of Pacific and Asian Studies, The Australian National University, Canberra.

Tran Thi Tâm Đan, 1999. 'Luat giao duc-co so phap ly de phat trien giao duc va dao tao [The education law-legal foundation to develop education and training]', Nhân Dân, 27 January. Available online at www.nhandan.org.vn.

Tran Chi Dao, Lam Quang Thiep, et al., 1995. 'Organization and Management of Higher Education in Vietnam: an overview', in D. Sloper (ed.), Higher Education in Vietnam, Institute of Southeast Asian Studies, Singapore:74-91. 